\title{
IDENTIFICATION AND EVALUATION OF SOME DETERMINING FACTORS IN THE CONSUMER DEMAND FOR APPLES IN THE TIRANA AREA
}

\author{
Dr.EGLANTINA PAZAJ \\ Agricultural University of Tirana, Department of Rural Development Policies, Tirana, Albania \\ email:epazaj@ubt.edu.al
}

\begin{abstract}
Knowing consumer preferences on the demand of different products is the key to success for different businesses. Different customers have different preferences regarding the demand for goods and services. Factors affecting demand determine the quantity required for a good. Some of these factors are: sales price, consumer income, consumer preferences, consumer forecasts for the future, substitute and complementary goods prices, etc. By knowing and analyzing these factors well we are able to determine consumer choices for goods and services. In this paper we will analyze how some of the factors determining demand affect apple consumption. The study refers to a survey conducted for casual consumers in the Tirana area on the preferences and quantities consumed by this product.
\end{abstract}

Key words: determining factors; preferences; demand, consumption.

\section{Main Problems and Objectives}

\section{Main Problems}

The need to study and examine consumer behavior is becoming more and more current. The consumer is seen as the key driver of the market and the expected profits of different firms, so companies should conduct a detailed market analysis to understand consumer needs and expectations, and identify the individual factors and incentives that impact consumers when buying products. with the aim of achieving the maximum satisfaction possible for them. As a result, market research and consumer recognition are also one of the main tasks of manufacturing and trading firms.

With this in mind, we focus our attention on studying consumer behavior and examining the impact of various factors that influence consumers on product purchasing. Specifically, at the beginning of the paper, we present some general theoretical insights on consumer behavior, consumer behavior, and factors that influence consumer behavior.

\section{Objectives}

Some of the main objectives of this study are:

- Identifying and evaluating consumer preferences referring to several different apple product attributes.

- Assessment of consumer willingness to pay depending on socio-economic characteristics.

- Observe consumer behavior in purchasing decision making when the determinants of demand change.

- Customer responsiveness to both domestic and imported product.

\section{Goals and methodology}

\section{Goals}


This paper focuses on the study of various factors that influence consumers in purchasing apple product. The reason we chose this fruit is related to the great value of the apple product but also to the fact that there is a high demand for this product and it is not lacking in the tables of every family. Apples are known for their tremendous nutritional value and ingredients to protect against a variety of symptoms and diseases.

\section{Methodology}

The methods used in this analysis consist of:

-The economic method

-Statistical analysis

-Customer Survey

-Official data

\section{Determinants of apple consumption demand}

The apple market, like any fruit and vegetable market, is a separate market due to the fact that products are easy to break down and because they represent an important food component for consumers. Because of these aspects, this market has many challenges from the production process to the distribution of end consumers.

To determine consumer behavior in relation to apples, a survey was conducted. The purpose of the survey was to analyze and examine the cognitive and emotional reactions to purchasing behavior and determine their rationality from the consumer's point of view. It consisted of two parts. The initial section asked respondents about their economic status, age, employment, monthly income and so on. The second part consisted of questions about the consumption of fruit in general and the apple product itself in particular. The feedback on the purchasing process for some product groups was analyzed. This survey process was conducted in the period May-June 2019 in the city of Tirana. There were 88 people who were randomly selected by the interviewer.

The most important factors of consumer behavior that are noticed in are:

\section{The economic situation}

These include the source and availability of the product, household income and percentage of income expenditure on food. It can be seen how the change in the economic situation, the average income per household, the change in the per capita income proportionally leads to a change in the amount consumed by the family. Thus a family with a large number of persons and a low average income would normally consume much less than a high income family. This is related to the price. We can say that price and consumption have an inverse proportional relation. So, as the price increases, the quantity consumed decreases. Respondents generally stated that prices are normal or high. And looking at households' monthly income we can say that it is a very important factor in deciding whether or not to consume the product.

\section{Demographic and social factors}

These include the number of family members, age, gender, education, resources, and leisure use. Thus, in addition to its use for food and cooking, it is noted that some respondents use it for aesthetic purposes. Normally this is observed in most female respondents as well as in younger ages. This has to do with information on new and different uses than the traditional apple as well as a good economic situation. So young ages and the female gender are more likely to consume more for this reason.

\section{Buyer confidence in product origin and food safety}


Today's consumer faces a wide variety of products, a variety of prices, a large number of providers in the market, so there is freedom of choice and replacement is very simple. Looking at the skeptical nature of the respondents and the lack of confidence in the quality and origin of the apple, we note two clusters. In the first group is the proportion of respondents who consume apples in normal or high quantities (2-3 times a week / 2-3 times a month). Here we note that they have established a line of trust with the supplier that in most cases is either from the village or from ambulance vendors. In the second group we observe those persons who deprive their diet of consumption of this product. Given the lack of confidence in the entire food security population in the country in all products, we can say that this is an important factor.

\section{Availability and replaceability}

Apples are a product that is readily available throughout the year due to refrigerated storage and resistance and quality preservation. Among the locally produced products we can say that this is the most consumed and this means that substitution can be made very rarely and this in periods or seasons where other fruits are consumed. So, the only products we can also find throughout the year are those imported. Among them are banana, kiwi and pineapple. They are also highly consumed but apples having high resistance and preserving physical hardness and other qualities at low temperatures at times make them more consumable and not easily replaceable.

\section{Customer preferences}

However good a product has in the end it will only be consumed if preferred by the consumer. Apples, given the widespread distribution and consumption in the Albanian population, we can say that it is preferable to most. So, the apple has no problem with preference being the most present on the table.

\section{People's expectations}

People's expectations can be very influential. People tend to act according to the course of action of the majority. However, it has less impact on the demand for apples than other factors. For example, let's say winter revisited in late spring with snow, which destroyed many apples (and other fruit) flowers.

\section{Price of replacement goods}

The effect of the price of substitute goods on the demand for apples is both large and small. Great because there are many substitutes for apples like pears and other fruits. If the price of these substitutes falls, people consume more of these commodities and less apples. At the same time, it is small because what causes the price of these substitutes to fall is likely to cause the price of apples to fall. In addition, even if the price of apples does not fall, pears and other fruits may not replace apples perfectly. For guest table cover, for example, there is as much room for apples as for pears or other fruits, no matter how different the price of apples is from the price of other fruits. In the case of apple juice, however, the substitute price is important because orange or other juices can easily replace apple juice.

\section{People's tastes or preferences}

Consumer taste is an important factor in the field of economics. If consumers change their attitude about the product positively, they will want more of it. Demand for any given price increases. Firms cannot increase supply immediately, so their first response is to raise prices. If consumers change their attitude negatively, the opposite happens. However, for apples, consumer tastes do not change from time to time. Health announcements regarding vitamins in apples affect demand, but not enormously.

\section{Statistical analysis and interpretations on appropriate consumption findings}

\section{Description of sample taken for analysis}

For the realization of this paper a direct field survey method was used. Thus, 88 random customers in the Tirana area were interviewed for this topic. The survey questions were of a demographic and economic nature. The 
purpose of this survey is to determine some of the factors affecting apple demand and consumer behavior when changing one of the factors affecting demand.

The following are some descriptive analyzes of the determining factors of apple demand.

Descriptive analysis of the determining factors of apple demand

During the interviews with consumers, several factors were identified that played an important role in the decision that consumers would make regarding the demand for the apple product to buy, the origin of the product, the place to buy, the price they would buy. be willing to pay etc.

Some of the factors are: gender, place of residence, employment, income, age, education, etc.

Listed below are customers rated by gender, residence, income, education, etc.

The following table gives the rating of customers by gender, age and occupation.

Table 1: Consumer ratings by gender, age, occupation. Descriptive statistics

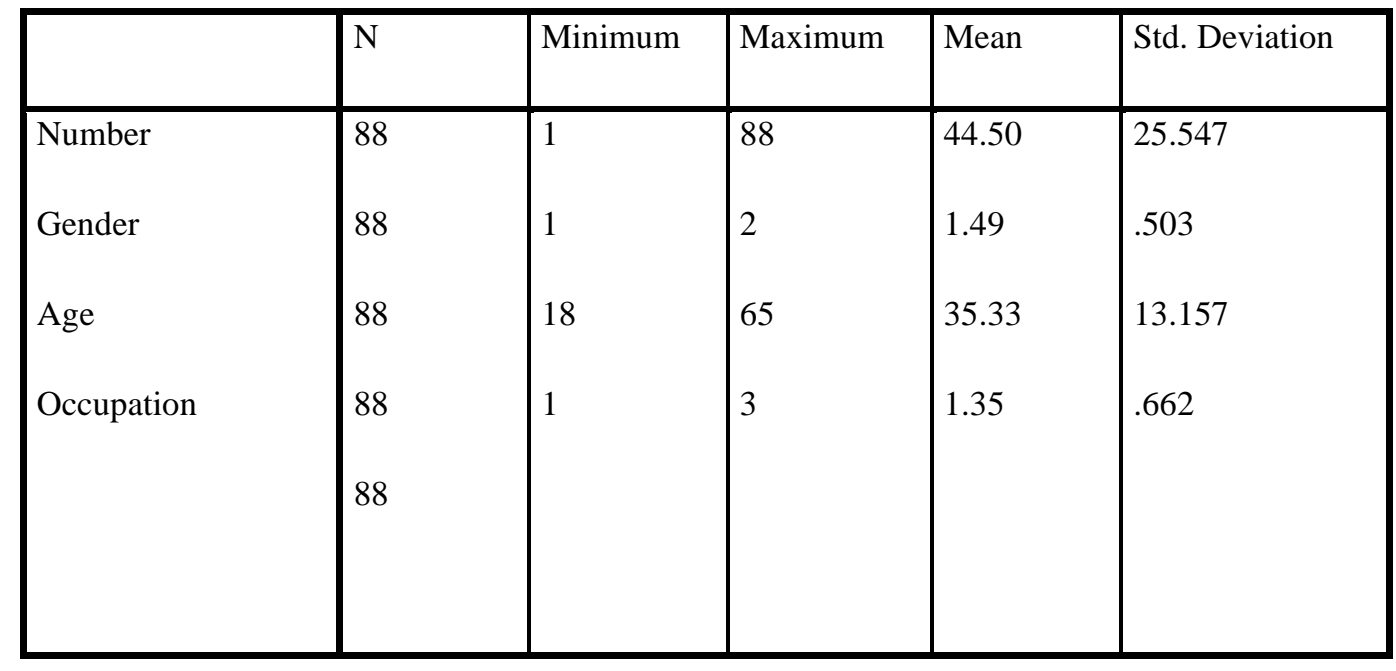

Table 2: Assessment by gender

\begin{tabular}{|c|c|c|c|c|c|}
\hline & & Frequency & Percent & Valid Percent & $\begin{array}{l}\text { Cumulative } \\
\text { Percent }\end{array}$ \\
\hline \multirow{3}{*}{ Valid } & Male & 45 & 50.6 & 51.1 & 51.1 \\
\hline & Female & 43 & 48.3 & 48.9 & 100.0 \\
\hline & Total & 88 & 98.9 & 100.0 & \\
\hline Missing & System & 1 & 1.1 & & \\
\hline Total & & 89 & 100.0 & & \\
\hline
\end{tabular}


Table 2 gives the consumer rating by gender, which shows that out of 88 consumers surveyed, 45 are male and 43 are female.

Table 3: Respondents' assessment by income level

\begin{tabular}{|ll|l|l|l|l|}
\hline & & Frequency & Percent & Valid Percent & $\begin{array}{l}\text { Cumulative } \\
\text { Percent }\end{array}$ \\
\hline & Low income & 29 & 32.6 & 33.0 & 33.0 \\
Valid & Average income & 43 & 48.3 & 48.9 & 81.8 \\
& High income & 16 & 18.0 & 18.2 & 100.0 \\
Missing & System & 88 & 98.9 & 100.0 & \\
Total & & 1 & 1.1 & 100.0 & \\
\hline
\end{tabular}

Table 4: Consumer rating of apple consumption

\begin{tabular}{|c|c|c|c|c|c|}
\hline & & Frequency & Percent & Valid Percent & Cumulative Percent \\
\hline \multirow{3}{*}{ Valid } & Po & 76 & 85.4 & 86.4 & 86.4 \\
\hline & Jo & 12 & 13.5 & 13.6 & 100.0 \\
\hline & Total & 88 & 98.9 & 100.0 & \\
\hline Missing & System & 1 & 1.1 & & \\
\hline Total & & 89 & 100.0 & & \\
\hline
\end{tabular}


Table 4 shows that 76 consumers responded that they consumed the apple while 12 consumers did not prefer the apple. Individuals have different tastes and preferences so to be in demand for a good is not only enough to be able to pay but you need to be at the same time ready and willing to have a preference for the product.

As can be seen from the table above, the majority of respondents consume the apple product once or twice a week, one of the reasons being that they consume other fruits alternately. Another reason is the low level of income that they can only provide for the consumption of basic commodities.

To make the statistical evaluation of the respondents, the linear model was used: $Y=a+b x+$, whereas the dependent variable is the consumers' income and the independent variable $\mathrm{X}$ is the employment of the respondents.

The following hypotheses have been raised to make a statistical assessment of income and employment:

Table 5: Estimation of the frequency of consumption

\begin{tabular}{|c|c|c|c|c|c|}
\hline & & Frequency & Percent & Valid Percent & $\begin{array}{l}\text { Cumulative } \\
\text { Percent }\end{array}$ \\
\hline \multirow{5}{*}{$\begin{array}{l}\text { Frecuency } \\
\text { of } \\
\text { consumptio } \\
\text { n }\end{array}$} & 1-2 times a day & 11 & 12.4 & 12.5 & 12.5 \\
\hline & 1-2 times a week & 42 & 47.2 & 47.7 & 60.2 \\
\hline & 1-2 times a month & 26 & 29.2 & 29.5 & 89.8 \\
\hline & Fare & 9 & 10.1 & 10.2 & 100.0 \\
\hline & Total & 88 & 98.9 & 100.0 & \\
\hline Missing & System & 1 & 1.1 & & \\
\hline Total & & 89 & 100.0 & & \\
\hline
\end{tabular}

Assumptions:

H0: There is no link between income and employment.

H1: There is a link between income and employment. 
Table 6: ANOVA between income and employment

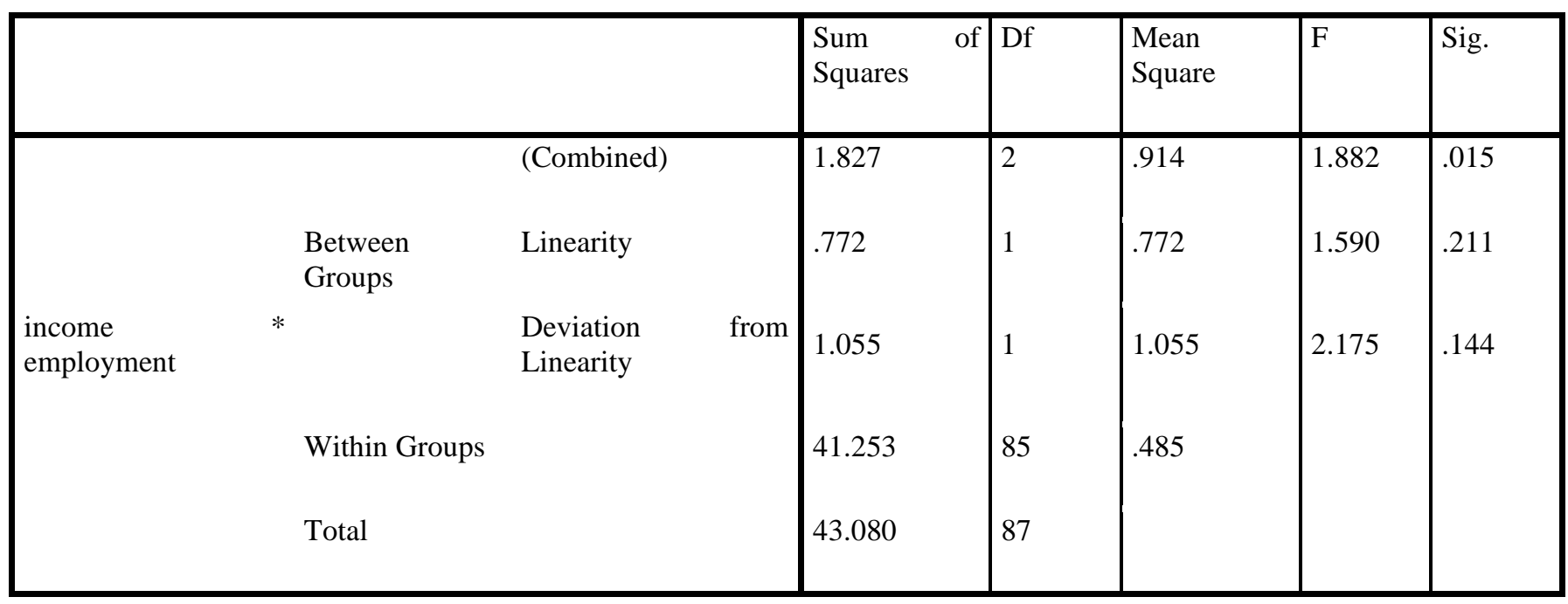

Table 7: Descriptive analysis between income and age

\begin{tabular}{|c|c|c|c|c|c|c|c|c|}
\hline & $\mathrm{N}$ & Minimum & Maximum & Mean & Std. Deviation & Variance & Kurtosis & \\
\hline & Statistic & Statistic & Statistic & Statistic & Statistic & Statistic & Statistic & Std. Error \\
\hline income & 88 & 1 & 3 & 1.85 & .704 & .495 & -.942 & .508 \\
\hline age & 88 & 18 & 65 & 35.33 & 13.157 & 173.097 & -.663 & .508 \\
\hline Valid N (listwise) & 88 & & & & & & & \\
\hline
\end{tabular}

From the statistical estimation in the following table, it can be seen that the value of $F$ is greater than the value of $0.05 \%$ security level. This means that the Ho hypothesis does not hold true and the H1 hypothesis holds. So, there is a link between income and whether consumers are in employment, school or have both.

This, table 7 provides a descriptive analysis of income and age.

In table 8, For the statistical evaluation of the respondents, the linear model was used: $\mathrm{Y}=\mathrm{a}+\mathrm{bx}+\mathrm{e}$ where the consumer income was taken as the dependent variable and the age of the respondents was taken as the independent variable $\mathrm{X}$.

\section{Assumptions:}

\section{H0: Income does not depend on age.}

\section{H1: Income depends on age.}


Table 8: ANOVA between age and income

\begin{tabular}{|c|c|c|c|c|c|c|}
\hline & & Sum of Squares & $\mathrm{df}$ & M0ean Square & $F$ & Sig. \\
\hline \multirow{3}{*}{ age } & Between Groups & 596.413 & 1 & 596.413 & 3.546 & .00033 \\
\hline & Within Groups & 14463.031 & 86 & 168.175 & & \\
\hline & Total & 15059.443 & 87 & & & \\
\hline \multirow{3}{*}{ income } & Between Groups & .007 & 1 & .007 & .014 & .907 \\
\hline & Within Groups & 43.073 & 86 & .501 & & \\
\hline & Total & 43.080 & 87 & & & \\
\hline
\end{tabular}

Even in this analysis the variance results that the value of $\mathrm{F}$ is greater than the $0.05 \%$ confidence level so $\mathrm{H} 0$ falls below and stands as true H1 meaning that the income level is age dependent.

\section{Coefficients $^{\mathrm{a}, \mathrm{b}, \mathrm{c}}$}

\begin{tabular}{|c|c|c|c|c|c|c|c|}
\hline \multirow[t]{2}{*}{ Model } & \multicolumn{2}{|c|}{$\begin{array}{l}\text { Unstandardized } \\
\text { Coefficients }\end{array}$} & \multirow{2}{*}{$\begin{array}{l}\text { Standardized } \\
\text { Coefficients } \\
\text { Beta }\end{array}$} & \multirow[t]{2}{*}{$\mathrm{t}$} & \multirow[t]{2}{*}{ Sig. } & \multicolumn{2}{|c|}{$\begin{array}{l}\text { 95.0\% Confidence Interval for } \\
\text { B }\end{array}$} \\
\hline & B & Std. Error & & & & Lower Bound & Upper Bound \\
\hline (constant) & 1.702 & .262 & & 6.488 & .000 & 1.173 & 2.231 \\
\hline Age & .007 & .007 & .144 & .952 & .346 & -.008 & .021 \\
\hline
\end{tabular}

a. Dependent Variable: income

b. Weighted Least Squares Regression - Weighted by profession

c. Selecting only cases for which gender $=$ male

$\mathrm{Y}=\mathrm{a}+\mathrm{bx}+\mathrm{e} \quad \mathrm{Y}=1.702+0.007 \mathrm{x}+\mathrm{e}$

Interpretation: with increasing age $(X)$ to 1 year, income $(Y)$ increases by $0.007 \mathrm{ALL}$ and $\mathrm{a}=1.702$ denotes income when $X$ is zero and the effect of other factors does not change (e).

Table 9: descriptive analysis---Descriptive Statistics

\begin{tabular}{|l|l|l|l|l|l|l|l|}
\hline & $\mathrm{N}$ & Minimum & Maximum & Mean & \multicolumn{2}{l|}{ Std. Deviation } & Variance \\
\cline { 2 - 8 } & Statistic & Statistic & Statistic & Statistic & Std. Error & Statistic & Statistic \\
\hline Daily price & 86 & 1 & 3 & 2.23 & .068 & .626 & .392
\end{tabular}


Table 10: The place where apples are bought

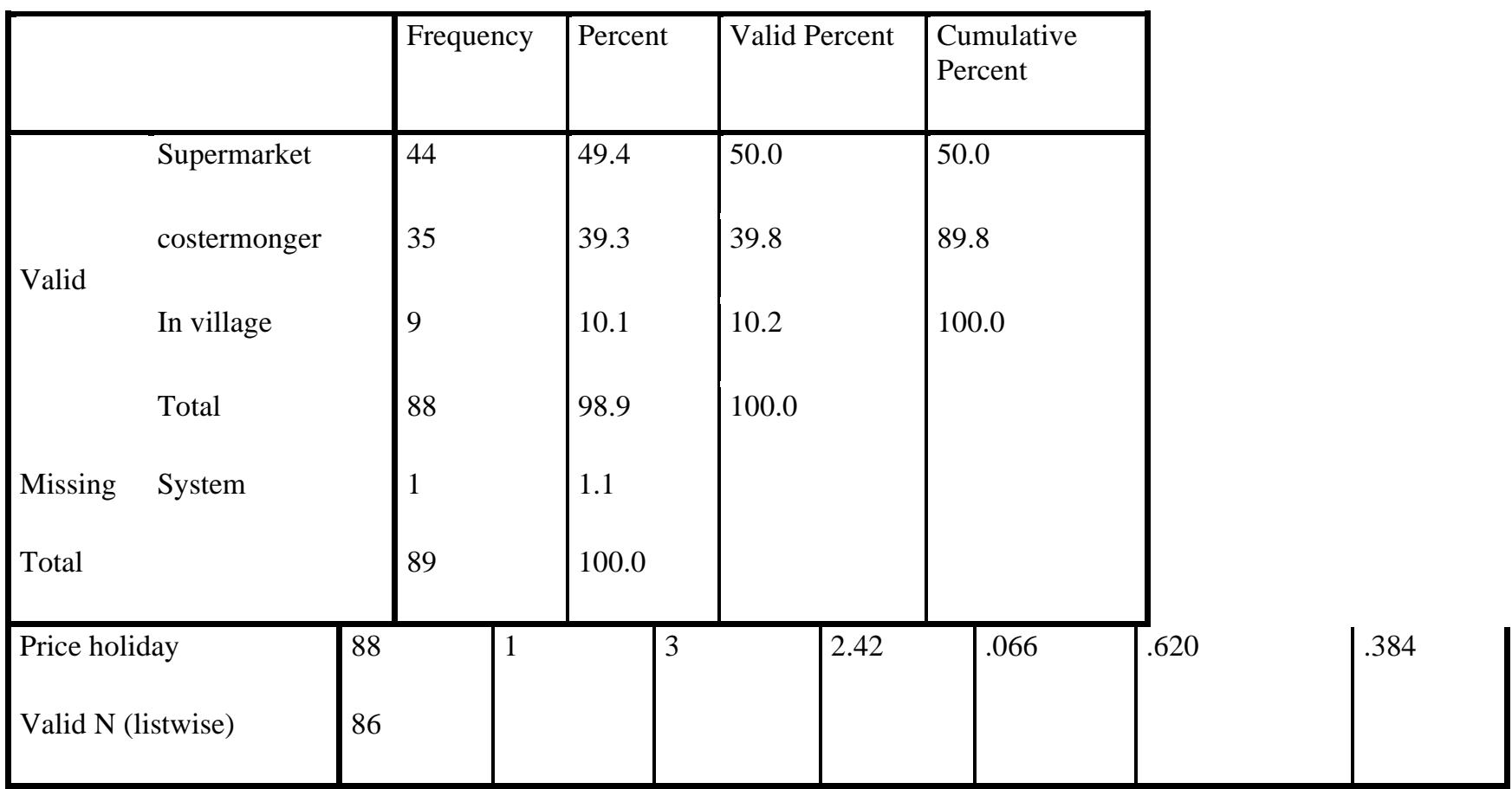

The table above gives a descriptive analysis of the price of apples daily and their price in the case of holidays.

As can be seen from Table 10, out of 88 consumers surveyed it results that 44 of them buy apple product at the supermarket because they feel safer there, 35 respondents buy it at out-of-town retailers who live in areas where they do not live. are very confident and 9 respondents make purchases in the village to their acquaintances because they believe that the product, they buy is bio.

Table 11: Daily price

\begin{tabular}{|ll|l|l|l|l|}
\hline & & Frequency & Percent & Valid Percent & $\begin{array}{l}\text { Cumulative } \\
\text { Percent }\end{array}$ \\
\hline & low & 9 & 10.1 & 10.5 & 10.5 \\
Valid & average & 48 & 53.9 & 55.8 & 66.3 \\
& high & 29 & 32.6 & 33.7 & 100.0 \\
Missing & System & 3 & 36.6 & 100.0 & \\
Total & & 89 & 100.0 & & \\
\hline
\end{tabular}

Table 11 shows that 9 of the respondents think that the daily price is low, 48 respondents think that the average price of apples varies daily and 29 respondents think that the price is high. 
Statistical refinements of the data from the 88 consumers survey reveal that factors such as apple price, fruit price, gender, age, employment, consumer preferences greatly influence consumers' decision to buy. . Changing one of these factors will make it change and the demand for the apple product positively or negatively depends on the factor that has changed.

\section{Conclusions}

The apple is a fruit that is available for most of the year and this makes it and the most consumed fruit in the country, at least when it comes to local produce.

As noted in the first section, price and availability are the deciding factors in the consumption demand for apples. The price of most of the respondents is defined as average, thus allowing it to be consumed without spending too much. Looking at nutritional values, the many ways of using it (including the aesthetic one that is most noticeable in younger ages and women) we can understand why it is even more preferable to a large number of respondents. (76 persons or $85 \%$ of respondents). Nearly half of respondents admit to consuming apples at least twice a week and at least $12.5 \%$ admit to consuming apples twice a day.

Below we note that there is a link between income and whether consumers are in employment, school or have both. Thus, that part of the higher income population (also in employment and / or work and school). ) consumes apples relatively more often than that lower-income portion with only school relationships. The higher the level of employment, the more it will affect the increase in consumption from income derived from employment.

The linear model $\mathrm{Y}=\mathrm{ax}+\mathrm{b}$ was used to judge whether there is a relationship between income and employment where the income level was taken as a dependent variable and as an independent variable employment.

Using Fisher F statistic, for its value higher than $0.05 \%$ alpha coefficient we came to the conclusion that H0: There is no relationship between income and employment declines and we accept H1: There is a relationship between income and employment. So, there is a link between income and whether consumers are in employment, at school or both.

On the other hand, we tried to find out if there is a relationship between income level and age, again using the linear model with dependent variable income level and age independent variable. From the equation obtained: $\mathrm{Y}$ $=1.702+0.007 \mathrm{x}+\mathrm{e}$, through Fisher's F statistic we regained the same results. For the $0.05 \%$ security level H0 drops down and we get H1: There is a relationship between income and age. Specifically, it results that with the increase of age by 1 year, the level of income increases by 0.007 ALL.

Finally, we can say that the statistical analysis shows that factors such as apple price, fruit price, age, gender, income, employment and consumer preferences will influence the decision to buy from consumers. The change in one of these factors will affect the change in demand for the apple product. However, whether the change will be positive or negative depends on the type of factor being changed and the extent of the change.

\section{Recommendations}

Internal market conditions and supply (land and climate, human capital and tradition) have been the main drivers of the development of the apple sector. Domestic demand will continue to support the development of the apple sector in the event of an improvement in the combination of growers to meet consumer preferences, so there is the potential to target high quality and higher priced consumer segments.

Packaging centers (refrigerated warehouses with marketing equipment) are needed to improve standards, also taking into account that in the future production growth will increase the pressure for exports (considering that the internal market is already saturated), and export markets are very competitive and demanding in terms of standards.

Given that a large proportion of respondents used apples for purposes other than consumption and cooking, the aesthetic would recommend investing in apple processing and derivative products (such as fruit juices, face aesthetics, shampoo etc.)....). The fact that there is a population that is increasingly attracted to these products 
ISSN 2661-2666 (Online) International Scientific Journal Monte(ISJM) DOI: $\underline{\text { 10.33807/monte.3.201912493 }}$

means that there is a good job market. This is also an investment that requires technology to preserve freshness and product quality so you would definitely need an investment in refrigeration equipment first. 


\section{Literature}

Bargh, J. A. (1994). The four horsemen of automaticity: Awareness, intention, efficiency and control in social cognition. Hillsdale, NJ: Lawrence Erlbaum.

Bass, V., \& Suzanne, F. (1999). Good intentions, bad habits and effects of forming implementation intentions on healthy eating. European Journal of Social Psychology, 29, 591-604.

Belk, R. W., Bahn, K. D., \& Mayer, R. N. (1982). Development and recognition of consumer symbolism.Journal of Consumer Research, 9(1), 4-17.

Cox, D. N., Anderson, A. S., Lean, M. E. J., \& Mela, D. J. (1998).UK consumer attitudes, beliefs and barriers to increasing fruit and vegetable consumption. Public Health Nutrition, 1(1), 61-68. 